\title{
FUTURE OF UNIVERSITY EDUCATION
}

$\mathrm{T}$ HOUGH the report (outlined on page 718 of this issue) of the Committee appointed by the British Association to consider university education after the War is only of an interim nature, it contains so much of outstanding and immediate value (if any of its proposals are eventually to be put into effect) that it warrants the close attention of all those interested in formal education and those who appreciate the valuable contributions which education will be able to make towards the new world order.

The Committee is obviously determined to pursue its policy of eliminating the defective and strengthening the weak spots in university education, of modifying certain systems and traditions, and of seeing that those universities which have suffered through the evil effects of actual warfare, or the even worse results of occupation by an unscrupulous enemy, are rehabilitated after the War. It is plainly anxious that all this shall be carried out in such a manner as to bring the maximum benefit not only to the universities immediately concerned but also to the whole international community. We tend at times to look upon university training as a means to an end which affects university men and women only; this is not only a very narrow but also a dangerous point of view, for universities are national institutions just like parliaments, and exist not only for the benefit of those who gain admission to them but above all for the community in general. The best material must be voted into them, and they must continue to make the best of that material so that their final products shall be not only a credit to themselves but also a distinct asset to the whole community.

Having read this interim report, we are satisfied that the Committee is treading the right path. It also indicates certain angles of approach which it proposes to make later on, and these indications, stated or implied, suggest that there will be much more for us to consider seriously when the final report becomes available. For that reason, only certain sections of the present report are sufficiently advanced to warrant useful comment.

The proposal that the 'modal' age of entry into the university should be nineteen is (apart from wartime contingencies) timely and deserving of support. Some of those actively concerned with university education have often expressed concern over the immature type of undergraduate gaining access to the universities. A first-year university student is in no way comparable to a sixth-form secondary school pupil, and the growing tendency to-day for a student to do his nominal first university year while still at school, and thus enter upon his second year when beginning his university career, makes the problem even more acute. When a student enters a university he finds himself thrown very much on his own resources, and often for the first time in his academic life has to make important decisions for himself in spite of university codes and regulations and tutorial supervision. Those university teachers who have had such students under their charge must often have noticed that many of them are too immature and indeed unready for such responsibilities.

Closely knit with the proposal to raise the age of entry, at any rate in its effect, is the Committee's proposal that a student should have given a year of national or international service or have had a year's oducation abroad before entering upon his university career, for thus will his mind be broadened and his sense of responsibility and of values be strengthened. Thus would students attain that greater appreciation of the value of social intercourse, greater maturity of mind and more experience of life, all of which have been so lacking for years past in our university freshmen. When they enter the university, they should be fit to take immediate advantage of the greater freedom from rules and regulations and of the fact that they are now treated as men and women and not as boys and girls. In present conditions too many fall victims to what is to them a new regime.

The comments of the Committee on entrance tests and scholarships will receive widespread support because such views have been expressed so often before, though, alas, little action has been taken. The present form of entrance examination is souldestroying. The teacher in the school is tied not only by the examination system, but also by the peculiar requirements of that university which his pupils hope to enter. Though we would be the last to press for absolute standardization at the expense of individual development and expression, we strongly support the Committee's suggestion that there should be some form of standardization of examination so far as general education is concerned. Specific and special knowledge must, if necessary, be tested individually; but such a requirement should be imposed only in exceptional cases, otherwise the evil effects of examinations will always be with us. The time is also propitious for those universities which insist on a pass in certain definitely stated subjects in their entrance examinations to pause to consider whether such provisos (for that is what they really are) are necessary and, indeed, whether such rulings are not harmful. We have no quarrel with the demand for a reasonably high standard in English, mathematics, science, and other subjects of cultural value; but it is difficult to see the reason for making such subjects as Latin or Greek compulsory, as certain universities do. It is well known that in many such cases, candidates, who have never studied Latin before, read enough, after passing their School Certificate examination, in order to pass university entrance, and then begin forgetting all about it. Surely, with all due respect to a sincere study of the subject, this short-term cramming is an unnecessary waste of time and is quite meaningless.

The most potent effect of the Committee's proposals concerning this type of examination will be felt in both directions, that is, beforehand in the schools and afterwards in the universities. A better type of 
student would be the universities' share, whereas in the schools the pupils would profit by equality of opportunity and a more all-round training, especially trom the social point of view.

It is recommended that all students should reside for at least one year in a university college or a hostel. It is also recommended that every student should be placed under tutorial supervision. These recommendations are complementary. But, though the Committee sets our minds at rest so far as expense is concerned, the difficulties will prove greater than one might on casual consideration think. Such difficulties as might arise will, of course, be least in the collegiate universities and in some of those modern universities, such as Reading and Manchester, which have developed splendidly comprehensive hostel or hall systems. The fraternity and dormitory systems extant in certain American universities would also lessen the difficulties. But a year's residence in a hostel would lose much, if not most, of its value if not lived fully and seriously. This would not be easy in many modern British universities situated in large towns which draw most of their students from their immediate surroundings. The hostel system in such cases would have to be subjected to very strict discipline if outside, especially home and town-life, distractions are not to exert a very adverse influence. Tutorial supervision is practised to a greater or less degree in most of our universities. In some, where it is scarcely anything but nominal, it needs tightening up. Much will depend upon the tutorial staff, who ought to be specially trained for the purpose, since they are more like teachers than lecturers. But the system itself would be greatly helped by some form of internal residence.

We can offer little but praise for the Committee's recommendations for re-planning teaching departments and curricula in accordance with modern conceptions of the interrelation of different branches of knowledge. In fact they have been borne out so recently as December 2 by the Archbishop of Canterbury, in a speech delivered in London, in which he said we should take note of the balance between human and scientific subjects. Dr. Temple considers that the pendulum has swung too far in the direction of scientific training. We tend to produce people whose conscious thinking is almost entirely governed by the methods of the laboratory, and whose minds only move freely when they are dealing with what can be measured, weighed and stated with exact pre. cision. As Dr. Temple claims, this is not true of any human problem.

This carries our minds back to an address made by the same speaker about twelve years ago in Manchester, when he pleaded for more research in the universities. This side of academic life has certainly developed, and there may lie the cause of the problem. Too much of the training of university students is left to research specialists. Research specialists are bound to give prominence to their own pet interests, and thus are often unable to strike a balance for the average student. It is clear that both the narrow specialist and the broad general teacher are required in the university of the future, for very often the best teacher in the university is only a second-rate research worker, and vice versa.

It is therefore with a feeling of deep satisfaction that we note the Committee's insistence on training for world citizenship in all faculties, pass and honours, of our universities. No university is justified in granting a first-class degree to a student who has simply passed satisfactorily through its faculty of science. Social studies and the humanities must play a certain part in the training of all students. This applies especially to science students, for it is almost axiomatic that, in present circumstances, a man might gain a first-class degree in science and be no more appreciative of the essentials of world citizenship than any less fortunate individual who has not gone so far as through a secondary school.

One misleading remark in the Committee's report is that its recommendations for the institution of honours and pass schools of "Philosophy, Natural and Social" would meet the "charges of neglecting the non-vocational education of citizens". It may be true that the ideal university education should not be influenced by vocational demands, but the fact still remains that nearly every university student treats his university career as a basis or qualification for a profession usually chosen beforehand. It is also true that those university departments whose subjects offer little or no vocational value often find themselves practically void of students. In this claim, the Committee seems to be too modest, for surely such a school of "Philosophy, Natural and Social" should prove to be the very best one for the future school teacher. In their examination syllabuses, the universities themselves are in large measure responsible for the narrow and far too specialized training given in our sixth forms; but another reason may be found in the type of honours man usually chosen for teaching such boys and girls. Give him, not an honours degree in one subject, but what the newly proposed course can offer, and then our university candidates from the schools would receive a wider training in sociology and citizenship than they do at present.

The Committee's attempt to link up natural and social philosophy in the history of discovery is deserving of very careful consideration. In our studies of discovery we are recommended to include "natural science or scholarship, studied in relation to social and political history". This should help university, and even school, teachers to break away from the belief that they are doing enough when they bring into their science courses the study of the works of such paragons as Newton, Faraday, Boyle, Darwin and Harvey. In this connexion, teachers are recommended to read Dr. H. A. Mess's "Social Structure", where a considerable amount of background is offered for such courses as are proposed by the Committee. For example, the period between 800 and 400 B.c. was notable for its advances in ethical thought. There we find such names as Lao-Tze, Gautama Buddha, and the Jewish prophets from Amos to the second Isaiah. In Greece during the fifth and fourth centuries before Christ, consider. able additions were made to knowledge, especially in 
mathematics, physics, medicine and biology. Socrates developed the method of argument, and Aristotle was the founder of formal logic. Rome followed during 100 B.C.-A.I, 400 with contributions to engineering, government and the formulation of law. And so one could go on. This is the history of discovery-not the discovery of natural laws alone, but also of human relations.

It is certain that our science students need a much broader and deeper background to their training. They need to be given training not only in scientific method but also in the interrelation of science with the other cultural disciplines. By giving them this we make them think of themselves not only as wheels in a machine concerned only with their own move. ments, but also as necessary parts of that machine, the working of which they seek to understand-the machine of human culture.

All this, the British Association Committee clearly bears in mind in its deliberations, and for this it is to be congratulated on a very valuable piece of work, which, nevertheless, is only partially completed. The Committee has, much to its credit, kept in mind the most important needs in our universities of the future, namely, equality of opportunity, freedom of development, thought and speech, the promotion of international collaboration, needs and service of the community-or in one phrase, training for world citizenship.

\section{BRITISH ASSOCIATION REPORT}

$\mathrm{O}$ $\mathrm{NE}$ of the important questions raised at the Conference on Science and World Order, which was held in London during September 1941, under the auspices of the British Association Division for the Social and International Relations of Science', was that of post-war university education and the rehabilitation of universities destroyed or damaged during the War. A Committee was consequently formed to examine and report on the problems involved. This Committee, under the chairmanship of Dr. J. C. Maxwell Garnett, is composed of twentyfour members (several representing universities outside the British Empire), together with the president and general officers of the British Association, and Prof. F. E. Weiss and Mr. A. Gray Jones as joint honorary secretaries. The Committee presented an interim report to the Council of the British Association in September 1942, and this has now been published $^{2}$.

\section{Entrance to Universities}

The Committee recognizes that those who enter upon a university career should do so with a greater maturity of mind and a wider experience of life than has hitherto been the case. 'The 'modal' age of entry into the universities should therefore be not less than nineteen. During their nineteenth year, students should carry out some approved form of national or international service (civil or military). Where possible, this work should be related to the intended profession of the students of applied science. For example, engineers should do a year of workshop training, and medical students might either enter a hospital or do some other form of welfare work. In other cases, a year abroad could be accepted as one form of international service.

Entrance examinations should consist of two parts :
(1) a test of general education ; (2) a test of special knowledge. So far as (1) is concerned, an everwidening group of universities (beginning with all those in the United Kingdom) should adopt each other's tests. This would not apply to (2), but each department of each university should satisfy itself concerning a candidate's special knowledge. Though this recommendation would not be seriously impaired if certain universities still insisted upon every candidate for matriculation possessing, as part of a general education, some one particular kind of knowledge (for example, Greek or Latin) not required by other universities in the group, the Committee expresses the view that the adoption of its recommendations should be subject to no such exception.

Personal character (purposefulness, enterprise, initiative and originality) should receive careful consideration, together with the generally examined knowledge and intellectual qualities of a candidate when he is being considered for a university entrance scholarship. One of the greatest advantages of this, so far as each individual is concerned, would be to increase equality of opportunity. The schools themselves would also benefit in that they would thus be encouraged to provide more all-round training, especially social, by means of out-of-school activities.

For every internal student, at least one year's residence in college or hostel should be enforced. The Committee states that this would not involve a prohibitive cost; but further inquiries are being made. Personal direction and watching of every undergraduate's studies should be more fully deve. loped by the adoption or extension of the tutorial system.

Freedom for discussion should be the keynote of all university education. Freedom of thought and expression, especially so far as world affairs are concerned, should be assured.

\section{An International Auxiliary Language}

International communication will be indispensable after the War, and the universities can contribute towards this by requiring all their students to be able to make themselves understood, by speech and writing, in some one auxiliary means of international communication. This is not a question of learning another language but of devoting one long vacation to the acquisition of an auxiliary means of communication. Basic English, for example, has only 850 words, whereas the English language contains 240,000, while French has 100,000 and Italian 80,000 words. A sufficient acquaintance with Basic English could be obtained within a few days by the many post-war students who will be able to talk some English. Professional diplomats can, of course, transact their business in a common language. Since it ceased to be Latin it has generally been French and is likely, in future, to be English. English is one of the two languages of the Anglo-Soviet Treaty and the common language of Generalissimo Chiang Kai-shek and the peoples of India.

The desirability of promoting the introduction of an auxiliary language as an international means of communication was given particular attention after the War of 1914-18, and the position and prospects of this subject were surveyed in a report of a British Association Committee published in 1921. In order to present the problem in a comprehensive manner, the Committee communicated with leading authorities and associations having special knowledge of classical 